\title{
Embriaguez, aprendizagem, performance, prazer
}

\author{
EMBRIAGUEZ, APRENDIZAJE, PERFORMANCE, PLACER
}

Carla Dias de Borba

\section{RESUMO}

O presente artigo/conferência apresenta um relato sobre a performance 7 Cabeças e suas reverberações no âmbito da pesquisa acadêmica em artes visuais. Tendo em vista o caráter múltiplo da performance 7 Cabeças, quanto jogo, plataforma de conhecimento, processo de partilha, sistema de aprendizagem, mesa de bar, metodologia, encruzilhada e manifesto feminista o texto revela a fala dionisíaca de uma artista a respeito da embriaguez e do prazer de estar em colaboração com mulheres em estado de performance.

PALAVRAS-CHAVE: Performance; Feminismo; Ludicidade

\section{Resumen}

El presente artículo / conferencia presenta un relato sobre la performance 7 Cabezas y sus reverberaciones en el ámbito de la investigación académica en artes visuales. En cuanto al carácter múltiple de la performance 7 Cabezas, cuanto juego, plataforma de conocimiento, proceso de partilha, sistema de aprendizaje, mesa de bar, metodología, encrucijada y manifiesto feminista el texto revela el habla dionisíaca de una artista acerca de la embriaguez y del placer de estar en colaboración con mujeres en estado de performance.

\section{PALABRAS CLAVE: Performance; Feminismo; Lúdico}

Iniciou este artigo/conferência ${ }^{1}$ dizendo, sou 'devota' a Dionísio o qual junto às Musas e à Apolo surgiram para fazer a felicidade da galera na paideia. Todos reunidos, seres mortais e imortais, brindaram à arte e à cultura ocidental. Platão pelas palavras de Huizinga já apontava,

Os deuses, diz ele, cheios de piedade pela raça humana, condenada ao sofrimento, ordenaram que se realizassem as festas de ação de graças como descanso para suas preocupações, e deram-lhes Apolo, as Musas e Dionísio como companheiros dessas festas, a fim de que esta divina comunidade festiva restabelecesse a ordem das coisas entre os homens. (...) como todas as criaturas jovens são incapazes de conservar em repouso seus corpos e suas vozes, como precisam movimentar-se constantemente e fazer ruídos de alegria, precisam correr, saltar, dançar e emitir toda espécie de gritos. Mas enquanto todas as outras criaturas desconhecem a distinção entre a ordem e a desordem, aos homens, os mesmos deuses que lhes foram dados como companheiros da dança conceberam a percepção do ritmo e da harmonia, a qual é invariavelmente acompanhada de prazer. (HUIZINGA, 2014, p.178-179)

Este texto/conferência diz respeito a questões presentes em minha pesquisa de doutorado em artes visuais ${ }^{2}$, são elas, a embriaguez, os processos de aprendizado, a performance e o prazer. Não me deterei em cada um desses termos, mas minhas reflexões orbitam a todos. Assim, convido você leitor a orbitar comigo (de preferência com uma taça de vinho em mãos).

\footnotetext{
1 Texto apresentado em conferência de abertura do evento "PerformAções" realizado em 2018 no Centro de Artes e Letras da UFSM, iniciativa do grupo de pesquisa LAPARC.

2 Atualmente sou doutoranda em poéticas visuais pelo Programa de Pós-Graduação em Artes Visuais da Universidade Federal do Rio Grande do Sul.
} 
Vivenciar o mundo como mulher e pela ótica feminista me abriu um leque imenso de novidades, surpresas e diferenças. Instaurou-se, tanto em meu processo artístico, como em minha relação com o outro, com o contexto e com a temporalidade, um despertar ético contra as formas de sujeição impostas às mulheres e contra a permanência das estruturas patriarcais, injustas e excludentes. Um despertar para o tempo presente, para o dia a dia das relações sociais, no aqui agora, no vivido, na corporalidade. Meu corpo vivendo o corpo do outro, diferenciando-se, identificando-se e entendendo os direitos de existir de todas e todos em suas espectivas singularidades.

Assim, a aproximação com os estudos feministas me conduziu à tomada de consciência de minha condição política e social de mulher branca, cisgênero, heterossexual, latino-americana, brasileira e privilegiada por diferentes aspectos, mas principalmente por fazer parte de uma pequena parcela de brasileiras com acesso ao ensino superior nível lato sensu. Por outro lado, a perspectiva dos feminismos só passou a fazer parte de minhas reflexões e percepções há pouco tempo atrás, fato que me deixou exposta à lógica da cultura misógina e machista, da qual carrego traumas e atos de resistências. Abismada, me questiono. Como, no Colégio de Aplicação da UFRGS, uma instituição de referência para a educação básica, de 1985 a 1995, o feminismo não foi, em nenhum momento, trazido à tona? Como, no Instituto de Artes da UFRGS, durante 1997 e 2003 não me dei conta e nem me alertaram que meu estudo e admiração envolvia, somente, a produção de arte masculina? Como, no Instituto de Artes da UFRGS, durante 1997 e 2003 nao me dei conta e nem me alertaram que meu estudo e admiração envolvia, somente, a produção de arte masculina? Como, em minha graduação, não entrei em contato com a produção das mulheres dos anos 60 e 70 ? Fato que, talvez, me levasse a encontrar os estudos feministas. Tanto se silenciou (suspiro profundo). Como náo gritar? Como não se embriagar e retomar a historia invisibilizada? Desse jeito, sem saber que já haviam disputas travadas contra o machismo, acumulei em minha memória do mundo patriarcal violento e injusto a luta de uma mulher, màe de três filhas, professora de teatro (dado que para a familia ja era algo incompreensível e envolto de promiscuidade), atriz até a maternidade, tornar-se incompatível com a estrutura machista do teatro da época (ou de sempre?) e, por fim, divorciada (um escândalo para uma mulher do interior trinta anos atrás). Essa junção de escolhas e situaçoes que caracterizavam minha mãe gerou um compenndio de adjetivos e expressoes ditas pelo meu pai e por familas que me marcaram: histerica, louca, gritona, desorganizada, vadia, incompetente, náo soube segurar marido, doente, irracional, exigente demais, inconsequente, risco para o marido das outras, mãe irresponsável, desnaturada, etc. No entanto, por incrivel que pareça, dessa experiência outra se seguiu, descobrimos quáo libertador era náo ter a figura masculina (marido e pai) em casa. Vivemos nós quatro, mãe e tres filhas, livres da intransigência e da dominação masculina. A casa, enfim, era só de mulheres. Nosso cotidiano era permeado por fluxos de ideias, por invenções de última e do fim de semana. Aprendemos a questionar, criticar, dar sugestōes e agir. Ríamos muito, brincávamos muito, dançávamos, brigávamos gritando e faziamos as pazes. Como era bom brigar sem ninguem mandar - brigar falando baixinho! A nossa casa, sem o agente opressor masculino, tornou-se um lugar propicio para a brincadeira, para a criaçao, para a autonomia e principalmente para descobriinos a força que tinhamos juntas. Assim, minha infancia também for marcada pelo o desejo e a possibilidade de reunir amigas e amigos para brincar e experimentar situaçoes de lib hoje a pensar na importância do retorno à experiência do brincar, do jogar, da ludicidade e principalmente do retorno ao regozijo dionisíaco, ou seja, à experiência com arte.

Assim, apresento 7 Cabeças $^{3}$, um jogo, uma plataforma de conhecimento, um processo de partilha, um sistema de aprendizagem, uma mesa de bar, uma metodologia, uma encruzilhada, um manifesto e, acima tudo, uma performance regida por mulheres e regada por doses de cachaça. O encontro tem como formato o jogo "Escravos de Jó" (jogo infantil de cantiga de roda), inclui a leitura em voz alta, e a repetição dos gestos de carimbar folhas, passá-las adiante e beber cachaça. Dito de outra forma, as mulheres carimbam papéis, leem textos críticos, debatem e bebem cachaça enquanto jogam e cantam. Textos contendo notícias e depoimentos sobre a vida da mulher na sociedade contemporânea são compartilhados entre as participantes, gerando atravessamentos no canto e mudando o ritmo da ação - ficando hora mais Enta ora mais tranquila.

É uma performance pautada na ideia de reunir mulheres para jogar e brincar. É um convite carregado pelo desejo de gerar um contexto propício para o sentido de liberdade e prazer e desprazer. Por meio da relação entre estética e ética promovidas pela arte e pelo jogo, a performance apresenta-se num misto de festividade, ordem e desordem, ritmo, harA e desarmonia, em um processo poético de potência política.

A performance 7 Cabeças teve sua primeira edição no Fórum Social Europeu (Paris), por isso, antes de tudo, preciso situar brevemente o contexto das discussões imigratórias na França, no período em que propus a performance. Em 2002, 7 cabeças vem sendo apresentada desde 2003, tendo suas primeiras edicōes realizadas na França (2003-2005) e posteriormente no Brasil (2009-2018) A cada ediçăo a temática da performance incorpora novas especificidades: na primeira apresentaçăo, em 2003 na França, mulheres imigrantes e ilegais de diferentes nacionalidades formaram o jogo no Fórum Social Europeu em Paris. Dois anos depois, em 2005, os estereétipos atrelados a imagem da

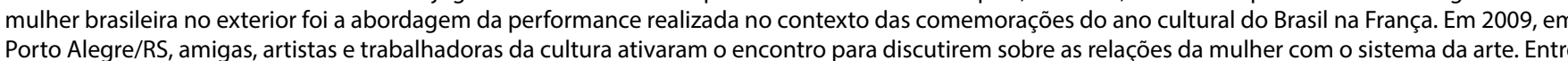
2015-2018 os encontros foram marcados por desigualdade salarial, direito ao aborto, abuso moral, entre outros.
Jacques Chirac venceu a eleição presidencial no segundo turno com grande vantagem de votos contra seu adversário Jean Marie le Pen do partido de extrema direita Front Nacional. ${ }^{4}$ Os franceses tiveram que correr para as urnas para garantir que Chirac assumisse o cargo. O candidato do tradicional Partido Socialista ficou de fora da disputa. Um dos aspectos que fez o candidato do Front Nacional disparar nas pesquisas diz respeito à crescente importância do problema da imigração na França. No período do Fórum Social Europeu o Ministro do Interior era o político Nicolas Sarkosy focado nas questões políticas vinculadas à imigração. Sarkosy apresenta para a Assembleia Nacional na época projetos de lei com teores mais restritivos quanto à entrada e à estadia de estrangeiros na França.

Dessa forma, os estabelecimentos da Prefeitura de Paris enfrentavámos filas, senhas, muita gente, brigas, espera, funcionários públicos franceses desanimados, mais espera, muita papelada, comprovantes, validades, datas, mais espera, carimbos, idiomas diversos, enfim, o retrato do serviço público que, a cada ano, foi se tornando mais restritivo e penoso para todos os estrangeiros. Foram nesses dias, nessas longas esperas, que conheci as outras seis mulheres que viriam a fazer parte da primeira edição da 7 Cabeças.

Minha realidade como imigrante era muito diferente da realidade de muitas colegas, pois a maioria buscava uma nova vida na França e tinham como meta se estabelecer no país. Eu, ao contrário, estava lá para estudar e usufruir da cultura francesa, coisa que se desenhou de forma diferente, mas por hora não vem ao caso. Durante o curso de francês, acabei acessando histórias de mulheres de diferentes países, entre eles Hungria, Mongólia, Tailândia, Colômbia, Peru, entre outros. Mulheres que regulavam de idade comigo e que, naquele ano, como eu, estavam com dificuldades em conseguir a estadia e o direito ao trabalho. Por isso, em nossos encontros, além de contarmos sobre nossos países, de fazermos comidas típicas, falávamos sobre os processos burocráticos dos bureaus de imigração.

Tinha como material o universo burocrático do serviço público francès, as historias de vida de minhas colegas estrangeiras e minhas reflexôes acerca da memória de infancia ' Fora isso e acima de tudo, eu sentia muita saudade dos botecos brasileiros! Eu desejava e salivava pelo acolhimento de um bar com uma mesa repleta de amigas, com as cachacinhas e os petiscos gordurosos! Dessa junçâo de experiências e desejos. (1) Cachaça e mesa de bar, (2) mulheres de diversas nacionalidades ávidas por conversas e por contar suas historias de vida; (3) memórias de infancia e (4) desejo de me embriagar emergiram lembranças, experiencias e imagens. Compreendi, assim, que contava com material para a criaçáo de um trabalho. "Escravos de Jo" é uma brincadeira de roda brasileira, a qual näo tem uma origem bem definida, mas popularmente sabe-se que o jogo porta um sentido de luta dos povos arricanos escravizados. Dizem ser uma estratégla de rebelião. São guerreiros que desafiam capitaes do mato em movimentos de zigue zigue zá, para fugir das senzalas. Foi o imaginário da fuga, da busca por liberdade e da estratégia de sobrevivencia que me fez escolher o jogo "Escravos de Jó", pois a performance 7 Cabeças passou a ser uma opção poética para driblar as normas de uma sociedade patriarcal e misógina.

Propor o jogo "Escravos de Jó" como trama da performance 7 Cabeças partiu do desejo de criar uma metáfora do sistema burocratico de concessäo de direlto a estadia na França e do sistema de regras e normas disciplinantes. Sistema que determina as relaçoes de poder no àmbito micro e macro da sociedade ocidental. Estrutura pautada pela economia neollberal que tem na explocçáo sua ferramanta de progresso e opressao. Sistema que privilegla a classe dom apropria das criticas e das açós alternativas a ele. Sistema que engole a tudo e a todos sem chance de escapar. A perfor-

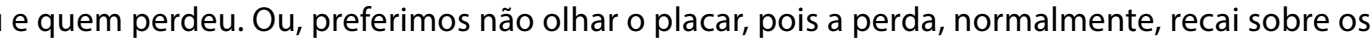
que pouco ganham. Ganhar ou perder, eis uma caracteristica dos jogos em geral e que não diz respeito à performance 7 Cabeças. Nela, todas escapamos da jogatina patriarcal e do impeto de ser melhor que a outra, pois do vicio da sociedade machista nos refugiamos no brincar/jogar, com nossas palavras, olhares e com a bendita cachaça. Essa última, que nos damos o direito de abraçar durante a performance, vem carregada de histórias e contradições. Contudo, considerando as reflexôes que havia desenvolvido para a primeira edição da performance, a escolha pela cachaça pontuou o desejo de incluir uma bebida brasileira no jogo, ou o desejo de oportunizar um porre brasileiro em terras e corpos estrangeiros. Assim, olhando com mais delicadeza para minha prática artística percebo a importância do brincar para o crescimento saudável da criança e para um devir-adulto igualmente saudável. Năo sel se me considero saudável no sentido pleno da palavra, mas minha intuição sempre me desloca para as experiências em que minha risada-gargalhada podem fluir solta. Devido a isso, começo a entender o quanto o brincar e o jogar sáo fundamentais e defendidos por estudiosos e por organizaçôes sociais em todo o mundo. No Brasil, o direito à brincadeira tornou-se lei em 1990, visto que o ato de bonsir ensivel para do conh do conhecimento, psicologia, história, pedagogia, sociologia, antropologia, educação, filosofia, entre outros. Por es 4 O partido Front National foi fundado em 1972. Tem como proposta unificar a direita radical francesa. A imigraçăo é uma pauta crucial do partido,
que a considerada um atentado contra a cultura e a economia francesa. O eixo principal das últimas campanhas mescla a imigração com os assuntos de

5 Conforme Lei № 8.069 de 13 de julho de 1990, Capítulo II - Art. 15. A criança e o adolescente têm direito à liberdade, ao respeito eà dignidade como

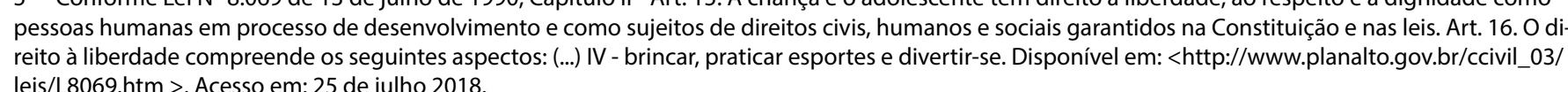
leis/L8069.htm >. Acesso em: 25 de julho 2018. 

razão, retomei minhas experiências de infância vinculadas ao jogo e à brincadeira. Acredito ser importante apresentar
aquilo que vislumbro como a energia vital da minha escolha de trabalho. Não posso negar que o entrelaçamento entre o 作 aos processos aisthesicos, sempre estiveram presentes em minha trajetória.

Encontrei alguns aspectos na teoria do biólogo chileno Humberto Maturana, mais especificamente do seu livro "Amar e Brincar: fundamentos esquecidos do humano do patriarcado à democracia", os quais acredito serem relevantes para a reflexão: a ludicidade, a ideia de coletividade intrínseca ao brincar e ao jogar, bem como aos processos de colaboração. O biólogo parte da ideia de que a cultura de uma comunidade corresponde à conservação de uma rede de conversações pautadas num linguajear, o qual se origina do entrelaçamento do emocionar com a ação. Maturana diz que "é a emoção que define a ação." Nossos ancestrais, primatas bípedes, em determinado momento passaram a conviver por meio do linguajear, o que equivale à prática da "convivência em coordenaçōes de coordenaçōes comportamentais consensuais" (MATURANA, 2004, p.10). Dito de outro modo, o linguajear foi um modo de operar na convivência com o outro, e foi pela manutenção, de geração após geração, dessa estratégia cotidiana de convívio que as comunidades se formaram, na base das conversações. Para Maturana o que constitui a existência do ser humano é sua capacidade de conversar, mas principalmente um conversar com base na percepção das emoções. Por isso as emoçōes antecedem a fala, a linguagem e são as responsáveis pela forma como atuamos no mundo. $O$ estudioso retoma as investigações da arqueóloga lituana Murija Gimbutas sobre sua análise de artefatos encontrados na região do Danúbio, nos Bálcãs e no Egeu, a partir dos quais elaborou a pesquisa tanto sobre a Europa Antiga quanto sobre as práticas de culto ao divino feminino. A partir dela, propoe a ideia de cultura matrística, correspondente à comunidades de agricultores e coletores, nômades que seguiam as imigraçóes dos animais dos quais se serviam. Náo estabeleciam propriedade, năo demarcavam e fortificavam seus povoados. Por meio dos artefatos (pinturas-murais e túmulos) encontrados por Gimbutas, os povos matrísticos demonstram uma equidade entre os integrantes das comunidades pré-patriarcais. O linguajear era centrado na ideia de harmonia em contínua transformação, cíclica entremeada de morte e nascimento. As conversaçōes que alicerçaram a cultura matristica eram de "participação, inclusão, colaboração, compreensão, acordo, respeito e co-inspiração. " (MATURANA, 2004, p. 42).

A convicção de Maturana sobre a cultura matrística ao mesmo tempo me delicia e me inquieta. E uma descrição de muita harmonia, muito peace and love. Penso que a desconexáo e tanta, nos dias atuais, que imaginar um contexto de respeito, colaboraçao, compreensăo e uniáo parece a descrição de uma imagem de outro planeta, repleto de extraterrestres eco-conscientes, está táo doente que só a imaginaçăo e a ficçăo-cientifica podem salvar nossas almas. Um brinde aos corpos embriagados! No entanto, o biólogo chileno me fisgou quando diz que esse contexto matrístico parece se concretizar na infância, mais especificamente no brincar e na ludicidade.

Já a cultura patriarcal, do ponto de vista de Maturana, se instaura quando algumas comunidades passaram a defender as manadas de animais migratorios de outros animais, gerando desse modo o sentido de apropriação e propriedade. 0 ato de matar animais deixou de ser um ato sagrado vinculado a um sistema de coerencia harmônica de convivencia. $O$ lobo tornou-se o inimigo e uma ameaça à nova ordem. A vida pastoril e a rede de conversaçăo instaurada pelo emocionar da apropriaçăo e pela defesa da manada acionou tambem outras sensaçoes no seio da comunidade, como a perda de confonça na coescia eno equilibrio natural da existenaia, insegu senç, in foco na procriação como ideia de acúmulo e segurança. A mulher torna-se propriedade do homem a partir da associação com a procriaça. Assim como a remea da manada, a mulher tambem gera riqueza ao ser a fonte da foça de trabalho. Essa nova estrutura social engendrou uma sociedade gerida pelos desejos de dominaçáo e controle dos outros e da natureza, pelo ímpeto de autoridade e apropriaçao, estabelecendo hierarquias e processos de grupos de excluídos e inimigos, validando princípios universais e transcendentalmente válidos, legitimando a competição, sustentando privilégios em prol de um progresso autoritário e violento.

Contudo, o resquício da cultura matrística está contido nas experiências da infância, durante o brincar e mediante as interações corporais com o adulto responsável por sua formação. A mútua aceitação entre os agentes que vivenciam o brincar remete aos processos de conversação matrística de coinspiração e cooperação, gerando consensos e acordos. Promovem respeito mútuo $e$, consequentemente, o autorrespeito. A interaçáo com o outro é orientada para o aqui e agora, e năo para a produçăo de resultados. Maturana junto com a autora Gerda Verden-Zoller propôem que o desejo de vivenciar e instaurar a plena democracia diz muito de um desejo de "(...) recuperar a dignidade, o auto-respeito e o respeito pelos outros." (MATURANA, 2004, p. 109). E ainda, "(...) Também afirmo que queremos recuperar tudo isso somente à proporção que jă o vivemos em, 2004, p. 109). E a

Para compor a ideia referente à cultura matrística e aos saberes atrelados à conexão com natureza, recorro à figura da bruxa, descrita por silvia Federici. A bruxa correspondia a mulher que possuía o conhecimento provindo da natureza, o qual The dava o pod por con parteiras, que se atreviam a viver sós, desobedientes ereb

O objetivo da tese da filósofa ítalo-estadunidense diz respeito ao trabalho de reinterpretação da história do capitalismo pelo viés feminista. Ela propõe que a história das mulheres mudou intrinsicamente no período da transformação
na conjuntura política, social e econômica da sociedade. A "transição" do sistema feudal para o capitalista, no continente europeu, remodelou a estrutura das comunidades feudais, expropriando não só a terra, mas também o corpo das mulheres e homens camponeses, os quais vinham de lutas infindáveis na Idade Média por uma sociedade baseada no compartilhamento de riquezas contra o autoritarismo e a hierarquia. Assim, "É na luta antifeudal que encontramos o primeiro indício na história europeia da existência das raízes de um movimento de mulheres que se opunha à ordem estabelecida e contribuía para a construção de modelos alternativos de vida comunal.

Dessa breve'cutucada'federiciana, proponho que imaginemos que cada um de nós carrega no DNA um desejo poderoso e quase inalcançável de desfrutar de uma experiência pautada nas descrições da cultura matrística de Maturana. Por vezes, em alguns instantes, quando observo crianças brincando livres e autônomas, parece que ali, naquele ajuntamento, o tempo e o espaço ganham outra dimensão. Talvez se eu pudesse voltar no tempo para observar mulheres reunidas nas terras comunais nos meados da Idade Média eu teria essa mesma percepção. Não tenho certeza como nomear essa experiência, sabendo que não são as certezas que pautam essa percepção. Talvez precisemos voltar nossa atenção para a aisthesis, como propõe Medeiros. Dito isso, ressalto que tudo o que foi posto aqui nessas páginas são divagações repletas de dúvidas e medos, que proporcionam um impulso para a coragem de dizê-las. Um texto catapultado ora pelo contrapeso do medo, ora pela coragem. Mas acima de tudo, por uma força que me faz convidar pessoas para brincar, jogar e performar. Um brincar que equivale à instauração de um espaço de escuta e de fala, no âmbito da arte, por meio de uma experiência lúdica e visceral, que parece ativar memórias, alegrias e revoltas. Talvez memórias matrísticas? Talvez memórias dos tempos de bruxaria?

\section{Referência Bibliográfica:}

FEDERICI, Silivia. Calibã e a Bruxa: mulheres, corpo e acumulação primitiva. Editora Elefante: São Paulo, 2017 disponível http://coletivosycorax.org/wp-content/uploads/2016/08/CALIBA_E_A_BRUXA_WEB.pdf

HUIZINGA, Johan. Homo Ludens. O jogo como elemento da cultura. São Paulo: Ed.Perspectiva, 1996

MATURANA. Humberto. VERDEN-ZOLLER, Gerda. Amar e brincar: fundamentos esquecidos do humano do patriarcado à democracia. São Paulo: Palas Athenas, 2004. 